前庭暗細胞に括けるカルシウムチャンネルの存在

\begin{tabular}{|c|c|}
\hline 井門謙太郎1)・森 & 良樹1)・夜陣 \\
\hline 康夫 ${ }^{1)} \cdot$ 天野 & 託 ${ }^{2)} \cdot$ 辻山 \\
\hline 征史 ${ }^{2)}$ - 田村 & 豊3) • 赤池 \\
\hline
\end{tabular}

\title{
Existence of $\mathrm{Ca}^{2+}$ Channel in Vestibular Dark Cells
}

\author{
Kentaro Imon, Yoshiki Mori, Kohji Yajin, Yasuo Harada, \\ Taku Amano, Shuji Tsujiyama and Masashi Sasa \\ (Hiroshima University) \\ Yutaka Tamura and Akinori Akaike \\ (Fukuyama University)
}

\begin{abstract}
To determine whether the functional $\mathrm{Ca}^{2+}$ channel exist in the vestibular dark cells, an increase in intracellular $\mathrm{Ca}^{2+}$ concentration $\left(\left[\mathrm{Ca}^{2+}\right] \mathrm{i}\right)$ due to high $\mathrm{K}^{+}$application was measured in dark cells isolated from the ampullae of the semicircular canal of the guinea pig using the $\mathrm{Ca}^{2+}$ sensitive dye, Fura-2, and digital imaging microscopy. When $40 \mathrm{mM} \mathrm{K}^{+}$ was added to the bath, there was a rapid increase in $\left[\mathrm{Ca}^{2+}\right] \mathrm{i}$ which returned to the original level after washing. Application of the $\mathrm{Ca}^{2+}$ channel blocker, nifedipine $(1 \mu \mathrm{M})$ blocked the incraese in $\left[\mathrm{Ca}^{2+}\right]$ i. These results suggest the existence of voltage-dependent $\mathrm{Ca}^{2+}$ channels in the dark cells, which are presumably involved in the regulation of $\mathrm{Ca}^{2+}$ concentration in vestibular endolymph.
\end{abstract}

Key words: $\mathrm{Ca}^{2+}$ channel, vestibular dark cells, Fura-2, nifedipine

緒言

前庭暗細胞は三半規管膨大部稜基底部, 卵形 豊前後壁，扣よび総脚の広範な部位に存在する 非感覚上皮細胞である. 暗細胞はその形態学的 特徵が他のイオン輸送機能を持つ細胞に類似し ていることから，何らかのイオン輸送に関与し ているのではないかと考兄られてきた11。その 後の研究により, 暗細胞は内リンパヘの $\mathrm{K}^{+}$の 分泌拈よび $\mathrm{Na}^{+}$の吸収機構を持つと考兄られ るよらになったが2) 8), 他の機能についてはま
だ推測の域を出ていない,一方, 形態学的観察 から，暗細胞は耳石の吸収に関与していること が $\operatorname{Lim}^{9)}$, Harada ら ${ }^{10)}$ によって示唆されている. 近年, Yoshihara $5^{11)}$ は $\mathrm{Ca}^{2+}$-ATPase 活性が 暗細胞の基底膜に沿って見いだされることから， 暗細胞は内リンパ液の $\mathrm{Ca}^{2+}$ 濃度の調節に重要 な役割を果たしているのではないかと推定して いる.しかし, 暗細胞が実際に $\mathrm{Ca}^{2+}$ 輸送に関 与しているか否かはなお不明である.

今回我々は暗細胞が $\mathrm{Ca}^{2+}$ チャンネルを介し

1）広島大学医学部耳鼻咽喉科学教室

2) 広島大学医学部薬理学教室

3）福山大学薬学部神経薬理学教室 
て $\mathrm{Ca}^{2+}$ 輸送を行なっているのではないかと考 えこのことを確かめるため単離した暗細胞を 用いて検討した.

\section{方法}

\section{1 ）細胞単離}

実験には, 生後 $4 \sim 6$ 週の有色モルモット (体重 $200 \mathrm{~g}$ ) 14匹を使用した．細胞単離の方法 は Wanngemann ら ${ }^{12)}$ 扝よび Yamashita ら ${ }^{13)}$ の手法を参考にした，有色モルモットをpentobarbital $(25 \mathrm{mg} / \mathrm{ml})$ にて麻酔を行い, 開頭後 内耳を含む側頭骨を摘出し，素早く低温の (4 $\left.{ }^{\circ} \mathrm{C}\right)$ 人工外リンパ液に移した。実体顕微鏡下に 3 個の半規管膨大部を骨より分離摘出した.

今回の実験には膨大部稜の両側に存在する暗 細胞領域のみを使用した。暗細胞の下に存在す る結合組織のメラノサイトが良い指標となるが, 最終的な同定は高倍率下 $(600 \times)$ の形態学的形 状により行なった。暗細胞領域のみを帯状に摘 出し, $0.25 \mathrm{mg} / \mathrm{ml}$ collagenase (Wako Pure Chemical Industries Ltd) にて20分間処理し, 室温下にピペッティングにて細胞を単離した。 単離した細胞は polyethylenimine (Sigma)を コーティングしたカバーグラス上に付着させ， 人工外リンパ液を満たした小水槽 $(1.5 \times 2.5 \times$ $0.5 \mathrm{~cm})$ 内に室温にて保持した.

2 ) 細胞内 $\mathrm{Ca}^{2+}$ 濃度の測定

細胞内 $\mathrm{Ca}^{2+}$ 濃度 $\left(\left[\mathrm{Ca}^{2+}\right] \mathrm{i}\right)$ は, $\mathrm{Ca}^{2+}$ 感受性 蛍光色素Fura-2 を用い， 2 個の異なる波長の 光に対する営光強度の比より計算される。 Fura-2 の蛍光は $\mathrm{Ca}^{2+}$ 濃度の増加により，340 $\mathrm{nm}$ の光に対してはその蛍光強度が増加し, 380 $\mathrm{nm}$ の光に対してはその蛍光強度が減少すると いら性質があるので, $\mathrm{Ca}^{2+}$ 濃度はこの 340/380 $\mathrm{nm}$ の比を利用して計算した。

単離細胞を保持した人工外リンパ液に $5 \mu \mathrm{M}$ Fura-2/AM (Dojindo) を加兄，室温にて60分間 保持した. この小水槽容器を光学顕微鏡 Olympus IMT-2 のステージの上にのせ, MCID Image Analysis System (Neurosciense)を用いて 細胞内の $\mathrm{Ca}^{2+}$ をイメージングし, 解析し, 測
定した。

3) 溶 液

人工外リンパ液の組成は， $150 \mathrm{mM} \mathrm{NaCl} ， 5$ $\mathrm{mM} \mathrm{KCl}, 2.5 \mathrm{mM} \mathrm{CaCl} 2,1 \mathrm{mM} \mathrm{MgCl}_{2}, 0.2$ $\mathrm{mM} \mathrm{Na} \mathrm{HPO}_{4}, \quad 0.4 \mathrm{mM} \quad \mathrm{KH}_{2} \mathrm{PO}_{4}, \quad 12 \mathrm{mM}$ HEPES，および $10 \mathrm{mM}$ glucoseより成り， pH 7.4 亿補正し，浸透圧は 300 Osm に補正し た. 単離細胞を含有する小水槽には，この人工 外リンパ液を micro perpex pump (Pharmacia) を用いて $3 \mathrm{ml} /$ 分の速度にて灌流した。 人工外 リンパ液に溶解した nifedipine (Sigma) および 高カリウム液 $(40 \mathrm{mM} \mathrm{KCl})$ は，灌流系を介し て水槽内へ投与した.

\section{結 果}

単離した暗細胞は球形を呈し，有毛細胞とは 明らかに区別することができた（図 1 )。人工外 リンパ液内の $\mathrm{KCl}$ 濃度を $40 \mathrm{mM}$ として灌流す ると 40 秒後に，小水槽内の $\mathrm{KCl}$ 濃度が $40 \mathrm{mM}$ に達した.この時点より単離した暗細胞 $\left[\mathrm{Ca}^{2+}\right] \mathrm{i}$ は著明に増加し，60秒以内に最高濃度に達した (図 2 ). $40 \mathrm{mM} \mathrm{KCl}$ 除去後, $\left[\mathrm{Ca}^{2+}\right] \mathrm{i}$ は減少し ていき， 3 分以内に高 $\mathrm{KCl}$ 負荷前の濃度に回 復した (図 $3 \mathrm{~A}) . \mathrm{KCl}$ 負荷後の $\left[\mathrm{Ca}^{2+}\right] \mathrm{i}$ の最高

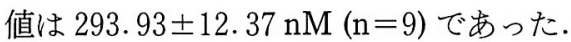

一方, dihydropyridine 系 $\mathrm{Ca}$ 拮抗薬である nifedipine $1 \mu \mathrm{M}$ を灌流液に加光て打いて，40 $\mathrm{mM} \mathrm{KCl}$ を負荷した場合には [ $\left.\mathrm{Ca}^{2+}\right] \mathrm{i}$ の増加は ほぼ完全に抑制された(図 3 B).

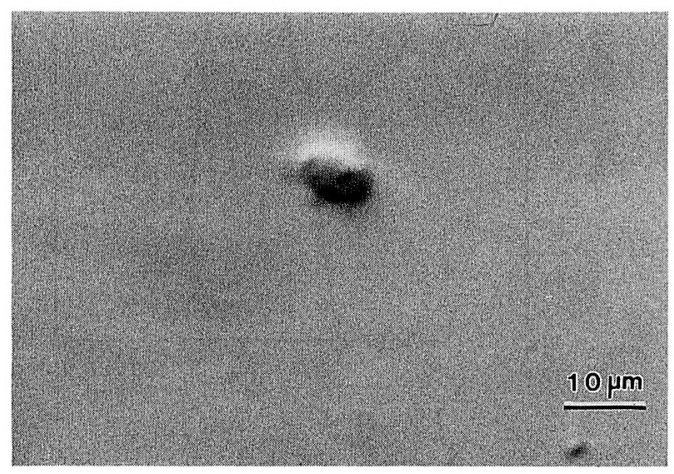

図 1 単離前庭暗細胞 


\section{考 察}

前庭特殊細胞の一種である暗細胞は，1907年 Kolmer14) が初めて記載している. その機能に ついては, 内リンパの分泌と吸収に深く関与し ていると考兄られてきた.1986年に Bernard

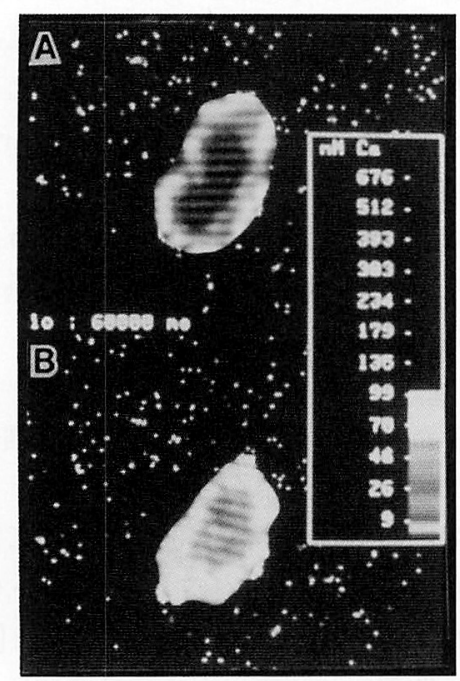

図 2 高 $\mathrm{K}^{+}$投与による単離前庭暗細胞内一 の $\mathrm{Ca}^{2+}$ 流入

$\mathrm{A}: 40 \mathrm{mM} \mathrm{KCl}$ 投与前 $\mathrm{B}: 40 \mathrm{mM} \mathrm{KCl}$ 投 与 80 秒後

\section{A: $40 \mathrm{mM} \mathrm{K}^{+}$投与時}

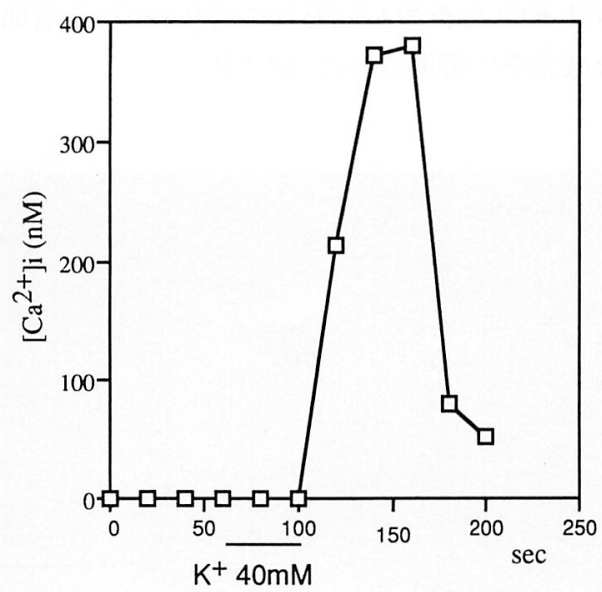

ら², 执よび1987年に Marcus ら ${ }^{3)}$ は, 暗細胞 は $\mathrm{K}^{+}$を外リンパより吸収し内リンパヘ分泌し ていると考光た。一方, Ferrary ら") は $\mathrm{Na}^{+} を$ 内リンパより吸収していると報告している. 最 近の研究により, 暗細胞のイオン輸送機構に は, $\mathrm{Na}^{+}-\mathrm{K}^{+}-$ATPase $と ~ \mathrm{Na}^{+}-\mathrm{K}^{+}-\mathrm{Cl}^{-}$cotransporter が関与することが示されている5). さらに 最近パッチクランプ法による研究の結果, 暗細 胞には二種類の $\mathrm{Cl}$ チャンネル6), 非選択性の 陽イオンチャンネル7)拉よび maxi-K チャンネ ル8)が存在することが明らかにされた.

一方, 内リンパ液の $\mathrm{Ca}^{2+}$ 濃度は $10^{-4}-10^{-5}$ $\mathrm{M}$ であり, 細胞外液の $10^{-3} \mathrm{M}$ に比べると低い が，細胞内液の $10^{-7} \mathrm{M}$ よりはるかに高い。こ のため内耳には, 内リンパ液の $\mathrm{Ca}^{2+}$ 濃度をあ る一定の濃度に保つ機構があると考えられてき た。 $\operatorname{Lim}^{9}$ は, 暗細胞表面に接している耳石が 虚脱している像を観察し, 暗細胞は耳石より Caを吸収していると考えた。この考光は Harada ら ${ }^{15)}$ が, 暗細胞表面に接している耳石 内の $\mathrm{Ca}$ が種々に減弱していることを観察した ことによっても支持されている.ささらに Yoshihara ら ${ }^{11)}$ は細胞学的手法により暗細胞の表面

B: $1 \mu \mathrm{M}$ nifedipineの存在下における $40 \mathrm{mM} \mathrm{K}^{+}$投与

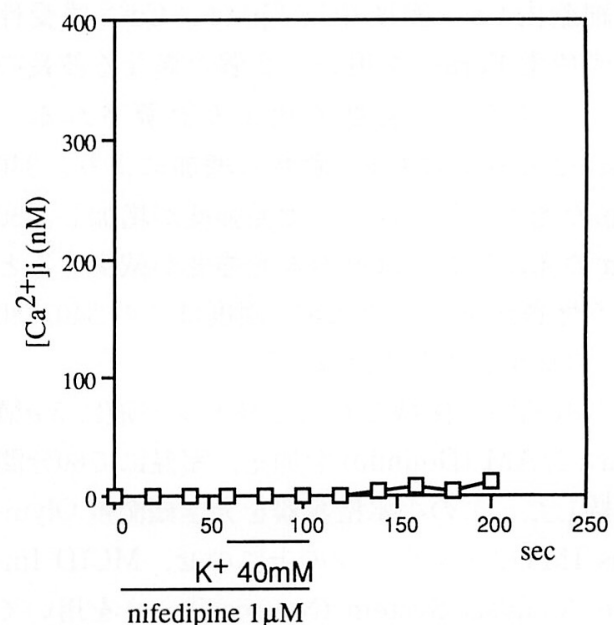

図 3 高 $\mathrm{K}^{+}$投与時の単離前庭暗細胞内 $\mathrm{Ca}^{2+}$ 濃度 
に $\mathrm{Ca}^{2+}$-ATPase 活性が強いことを見いだし， 暗細胞は内リンパ液の $\mathrm{Ca}^{2+}$ 濃度の調節に重要 な役割を果たしているのではないかと推定して いる. 我々は, 暗細胞のこのような $\mathrm{Ca}^{2+}$ 濃度 調節作用を証明すべく，高 $\mathrm{K}^{+}$刺激による暗細 胞内への $\mathrm{Ca}^{2+}$ 流入の測定を試みた。 $\mathrm{Ca}^{2+}$ 感 受性蛍光色素 Fura-2 を用いて, $\left[\mathrm{Ca}^{2+}\right] \mathrm{i}$ を測定 する方法は, 前庭器官ではすでに前庭有毛細胞 に応用され，多くの報告がある13)16) 19)．今回 我々は，Fura-2 を暗細胞に応用し， $\left[\mathrm{Ca}^{2+}\right] \mathrm{i}$ を 測定した. $40 \mathrm{mM} \mathrm{K} \mathrm{K}^{+}$負荷により，暗細胞内 $\left[\mathrm{Ca}^{2+}\right] \mathrm{i}$ は急速に増加し, 高 $\mathrm{K}^{+}$除去後には負 荷前のレベルへ戻った．高 $\mathrm{K}^{+}$により暗細胞が 脱分極を起こし，この結果 $\mathrm{Ca}^{2+}$ チャンネルが 開口して $\mathrm{Ca}^{2+}$ 流入が起こったと考えられる。 事実, 同一細胞に $\mathrm{Ca}^{2+}$ チャンネルブロッカー の Nifedipine を灌流しておいた場合には， $\mathrm{K}^{+}$ 負荷による $\left[\mathrm{Ca}^{2+}\right] \mathrm{i}$ 増加は完全に抑制されたこ とからも, 暗細胞には電位依存性の $\mathrm{Ca}^{2+}$ チャ ンネルが存在すると考えられる. 現在 $\mathrm{Ca}^{2+}$ チ ャンネルには $\mathrm{T}, \mathrm{L}, \mathrm{N}$ ，および $\mathrm{P}$ 型の 4 種が存 在する20). dihydropyridine 系 $\mathrm{Ca}^{2+}$ 拮抗薬であ る nifedipine により $\mathrm{Ca}^{2+}$ 流入が抑制されたこ とより, 今回認められた $\mathrm{Ca}^{2+}$ チャンネルは $\mathrm{L}$ 型チャンネルと考えられる.この $\mathrm{Ca}^{2+}$ チャン ネル機構は今後のパッチクランプ法による研究 により明らかにされると思われるが，㧤そらく 内リンパ液の $\mathrm{Ca}^{2+}$ 濃度の調節に関与している と思われる。

\section{まとめ}

1) $\mathrm{Ca}^{2+}$ 感受性蛍光色素 Fura-2 を用いて, 単離前庭暗細胞内の $\left[\mathrm{Ca}^{2+}\right] \mathrm{i}$ の变化を測定した.

2 ）暗細胞に $40 \mathrm{mM} \mathrm{KCl}$ を投与後, $\left[\mathrm{Ca}^{2+}\right.$ ]i は著明にかつ可逆的に増加した。

3 ) 同一細胞に Ca 拮抗薬である $1 \mu \mathrm{M} \quad \mathrm{Ni}$ fedipine を灌流液に加えた後に, $\mathrm{KCl}$ 負荷を行 った場合には， $\left[\mathrm{Ca}^{2+}\right] \mathrm{i}$ 増加は完全に抑制され た。

4 ）今回の実験により, dihydropyridine 系 $\mathrm{Ca}^{2+}$ 拮抗薬に感受性を持つ電位依存性 $\mathrm{L}$ 型力
ルシウムチャンネルが暗細胞に存在すると考兄 られた。

\section{文 献}

1) Kimura RS : Distribution, structure and function of dark cells in the vestibular labyrinth. Ann Otol Rhinol Laryngol 78 : 542 561, 1969.

2) Bernard C, Ferrary E and Sterkers O : Production of endolymph in the semicircular canal of the frog Rena esculenta. J Physiol Lond 371 : 17 28, 1986.

3) Marcus NY and Marcus DC : Potassium secretion by nonsensory region of gerbil utricle in vitro. Am J Physiol 253 : F613 F621, 1987.

4) Ferrary E, Bernard C, Oudar O, et al : Sodium transfer from endolymph through a luminal amiloride-sensitive channel. Am J Physiol 257 : F182 F189, 1989.

5) Marcus DC, Marcus NY and Greger R: Sideness of action of loop diuretics and ouabain on nonsensory cells of utricle ; a micro-Ussing chamber for inner ear tissues. Hear Res 30 : 55 64, 1987.

6) Wangemann $P$ and Marcus DC : The membrene potential of vestibular dark cells is controlled by a large $\mathrm{Cl}^{-}$conductance. Hear Res $62: 149 \sim 156,1992$.

7) Marcus DC, Takeuchi S and Wangemann $P$ : $\mathrm{Ca}^{2+}$-activated nonselective cation channel in apical membrane of vestibular dark cells. Am J Physiol 262 : C1423 C1429, 1992.

8) Takeuchi S, Marcus DC, and Wangemann P : Maxi- $\mathrm{K}+$ channel in apical membrane of vestibular dark cells. Am J Physiol 262 : C 1430 C1436, 1992.

9) $\operatorname{Lim}$ DJ : Formation and fate of otoconia ; scanning and transmission electron microscopy. Ann Otol Rhinol Laryngol 82 : 23 35, 1973.

10) Harada $Y$ and Sugimoto $Y$ : Metabolic disorder of otoconia after streptomycin intoxication. Acta Otolaryngol (stockh) $84: 65 \sim 71$, 1977.

11) Yoshihara $T$, Igarashi $M$, Usami $S$, et al : Cytochemical studies of $\mathrm{Ca}^{2+}$-ATPase activity 
in the vestibular epithelia of the guinea pig. Arch Otorhinolaryngol 243 : 417 423, 1987.

12) Wangemann $P$ and Marcus DC : Membrane potential measurements of transitional cells from the crista ampullaris of the gerbil. Pflügers Arch 414 : 656 662, 1989.

13) Yamashita $T$, Ohnishi $S$, Ohtani $M$, et al : Effect of efferent neurotransmitters on intracellular $\mathrm{Ca}^{2+}$ concentration in vestibular hair cells of the guinea pig. Acta Otolaryngol (stockh) Suppl $500: 26 \sim 30,1993$.

14) Kolmer $W$ : Gehörorgan. Handbuch der Mikroskopischen Anatomie des Menschen (ed by Mollendorff W). pp 250 478, Springer, Berlin, 1927.

15) Harada $Y$ and Tagashira $N$ : Metabolism of otoconia. Biomed Res Suppl 2 : 415 420, 1981.

16) Ohtani $M$, Yamashita $T$, Amano $H$, et al : Thermal influence on intracellular calcium concentration in vestibular hair cells isolated from the guinea pig. Acta Otolaryngol (stockh) Suppl
$500: 46 \sim 49,1993$.

17) Lapeyre PNM, Kolston PJ and Ashmore JF : GABA mediated modulation of ionic conductances in type I hair cells isolated from guinea-pig semicircular canals. Brain Res 609 : 269 276, 1993.

18) Ohmori $\mathrm{H}$ : Mechanical stimulation and Fura-2 fluorescence in the hair bundle of dissociated hair cells of the chick. J Physiol (Lond) 399 : 115 137, 1988.

19) Shigemoto $T$ and Ohmori $H$ : Muscarinic agonists and ATP increase the intracellular $\mathrm{Ca}^{2+}$ concentration in chick cochlear hair cells. J Physiol (Lond) $420: 127 \sim 148,1990$.

20）金子周司 : 神経の電位依存性 $\mathrm{Ca}^{2+}$ チャンネル. イオンチャンネルとレセプター実験医学(御子 柴克彦, 他編). 18 21頁, 羊土社, 東京, 1992.

$$
\left(\begin{array}{l}
\text { 別刷請求先 : 井門謙太郎 } \\
\text { 干734 広島市南区霞1-2-3 } \\
\text { 広島大学医学部耳鼻咽喉科学教室 }
\end{array}\right)
$$

